論文

\title{
周波数制御によるメタルハライドランプの高周波点灯
}

\author{
専門会員 水 野 銛 章 (名古屋工業大学) 非会員 林 宏 宜 (名古屋门業大学)
}

\section{High Frequency Operation of Metal Halide Lamp with Frequency Control}

Fellow Member Toshiaki Mizuno, Non-Member Hirotaka Hayashi

(Nagoya Institute of Technology)

\begin{abstract}
When a metal-halide lamp is operated by a sinusoidal wave of $10 \mathrm{k}$ to $100 \mathrm{kHz}$, arc instability caused by acoustic resonance occurs. The frequency regions for stable operation are narrow and vary with the operating condition. Therefore, it is difficult to operate the lamp at high frequency with a fixed frequency.

This paper presents a ballast for a metal-halide lamp. When the fluctuation of lamp voltage is large because of instability, the operating frequency of the inverter moves back and forth between $f_{\max }$ and $f_{\min }$, searching for a stable frequency. If the operating frequency coincides with a stable frequency and the lamp voltage fluctuation becomes small, so the operating frequency is maintained. Thus, the lamp operates at some stable point between $f_{\max }$ and $f_{\min }$.

Experiments performed with metal-halide lamp M100 $\cdot \mathrm{L}$ and stable operation at frequency range of $20-25 \mathrm{kHz}$ is confirmed.

This procedure reduces the interference with communication systems compared with square wave operation or frequency modulation.
\end{abstract}

KEYWORDS : metal-halide lamp, discharge lamp ballast, high frequency operation, frequency control

\section{1. まえがき}

一般に10 100kHzの周波数による点灯回路は，低い周波数に よる点灯回路に比べて回路素子LCが小型軽刴にできるという長 所があり, 䖢光ランプではインバー夕监光灯として商品化されて いる.また, $1 \mathrm{MHz}$ 以上の高周波点灯に比べて, スイッチング損 失や问路素子の損失を小さくでき，回路効㳯が高い。

このように10 $100 \mathrm{kHz}$ 带の点灯回路は, 小型軽量化と高効摔 の利点を有守るが, HID ランプをこの周波数の正弦波で占灯寸る と，音響的共鳴現象によりア一クの不安定や立ち消之を生ずる. 特に，メタルハライドランプでは $10 \mathrm{kHz}$ から $100 \mathrm{kHz}$ まで，㱠ど 連続的に不安定性を示寺。この間に数簓所の安定周波数領域が存 在するが, その帯域幅は $1 \mathrm{kHz}$ 以下と狭く, 同じ定格のランプで も安定周波数が㑬々の製品によりバラツキがあり, 電力や温度な どによっても変化する.このためメタルハライドランプを10〜100 $\mathrm{kHz}$ の周定周波数の正弦波により先定点灯亦ることは困難であ る.

音響的共鳴による不安定を回避するす法として，矩形波点灯， 第 3 高調波重量点灯, 周波数変調点灯, 每サイクル波長変化点灯 などがある1121. 音響的共鳴の原因はランプに入る瞬時電力の変化 であるので，矩形波により点灯すれば不安定は起こらない。ただ

本論文の一部は, 平成 8 年度照明学会全国大会（1996年 4 月）にて発表された.
し，このとき矩形波の立ちにがりと立ちドがりは急峻である必要 があり， $20 \mathrm{kHz}$ (周期 $50 \mu \mathrm{s}$ ) で許容瞬時変化は $2 \mu \mathrm{s}$ 以下である ${ }^{21}$. このような急峻な矩形波によれば，原理的には全周波数領域で交 定点灯が可能であるが, 高調波成分によるラジオノイズが大きい.

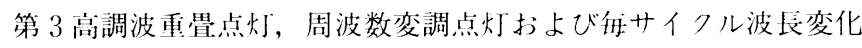
点灯では，涺弦波点灯に比べると努定点灯領域が店くなる。この 中で第 3 高調波重盢点灯は，高調波が第３次までであるのでラジ オノイズは小さい.

尚, ランプ発光管の形状の改良により音響的共鳴を回避古る研 究3)がある。また点灯周波数を高響的共鳴の起きる $10 \sim 100 \mathrm{kHz}$ り低くしたり，㙜く守れば文走に点灯できるので，低周波の知形

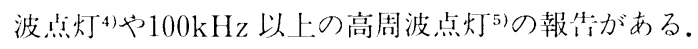

電子回路によりランプの点灯状態を監視して，不安定であれば 周波数をシフトし，安定周波数带域に入った時にその周波数を維 持するようにすると，岁定点灯が可能となる，著者の一人は先に マイクロコンピュー夕を用いた点灯回路について発表したがが, 今回はアナログ回路を主体と寸るものについて述べる。

\section{2. 周波数制御方式}

10 100kHzの周波数で点灯する時，岁定点灯のときにはラン プ電压の変動は小さいが，不安定状態ではランプ電压が不規則に 激しく変動する.ランプ電圧の変動を監視して，変動が大きい時 には周波数をシフトする占灯回路の動作を図 1 のフローチャート 
に示す。点灯周波数の上限を $\mathrm{f}_{\max }$, 下限を $\mathrm{f}_{\min }$ とする.まず, 上限 の $\mathrm{f}_{\max }$ にて始動し, 放電が安定ならば周波数はそのままで, 不安定 ならば周波数を下げるという動作を繰り返して,安定領域を探す. 周波数が下限 $\mathrm{f}_{\min }$ まで下がった時には，周波数を上げながら安定 領域を探し, 周波数が $\mathrm{f}_{\max }$ まで上がった時には, 再び周波数を下げ ながら安定領域を探す。このように周波数の上限と下限の間を往 復して安定周波数を探すので, この間に 1 個以上の安定領域が存 在すれば，安定に点灯する筈である.

安定領域の探し方を図 2 の(a)，(b)，(c)の3 通りが考えられる. (a)は上限と下限との間を上から下へ，下から上へと往復して探す ものである. (b)と(c)は探索領域の上端または下端から探し始め他 端に達したらりセットして元に戻り探索方向一定のもので, 回路 は簡単になるが，周波数が上端と下端との間をジャンプする時に

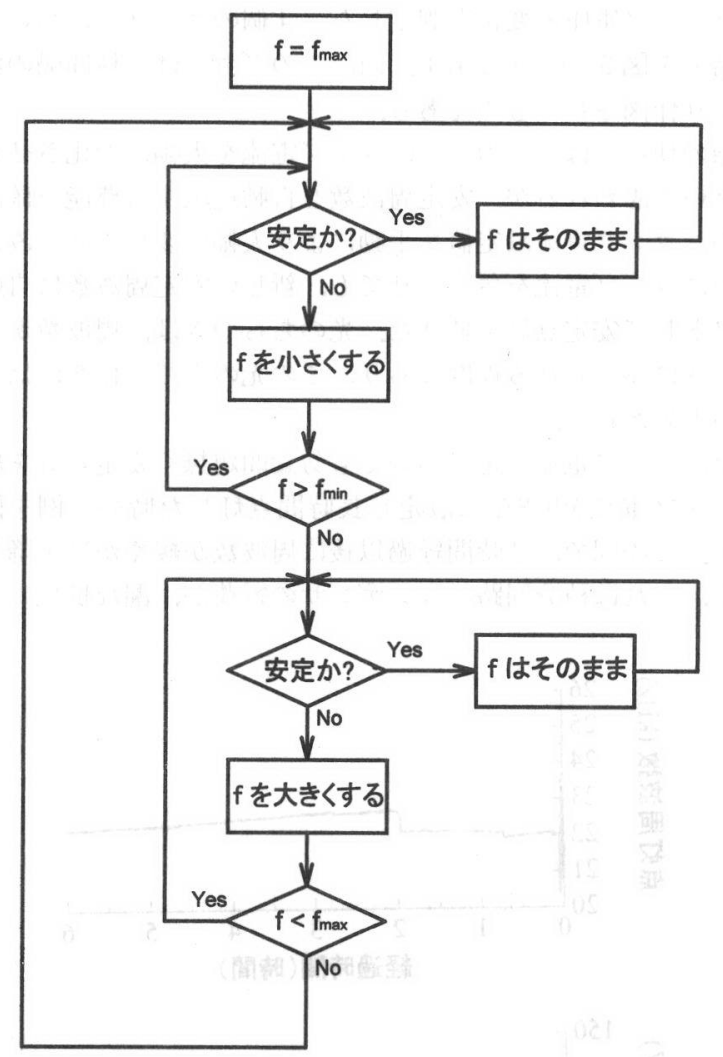

f : 点灯周波数

$f_{\max }$ 探索周波数带域の上限周波数 $f_{\min }$ : 探索周波数帯域の下限周波数

図 1 周波数制御のフローチャート

Fig. 1 Flowchart of frequency control.

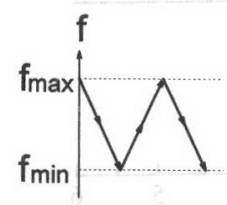

(a)

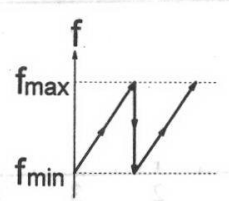

(b)

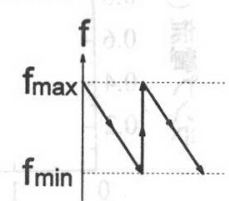

(c)
図 2 安定周波数の探索法

Fig. 2 Methods for searching stable frequency.

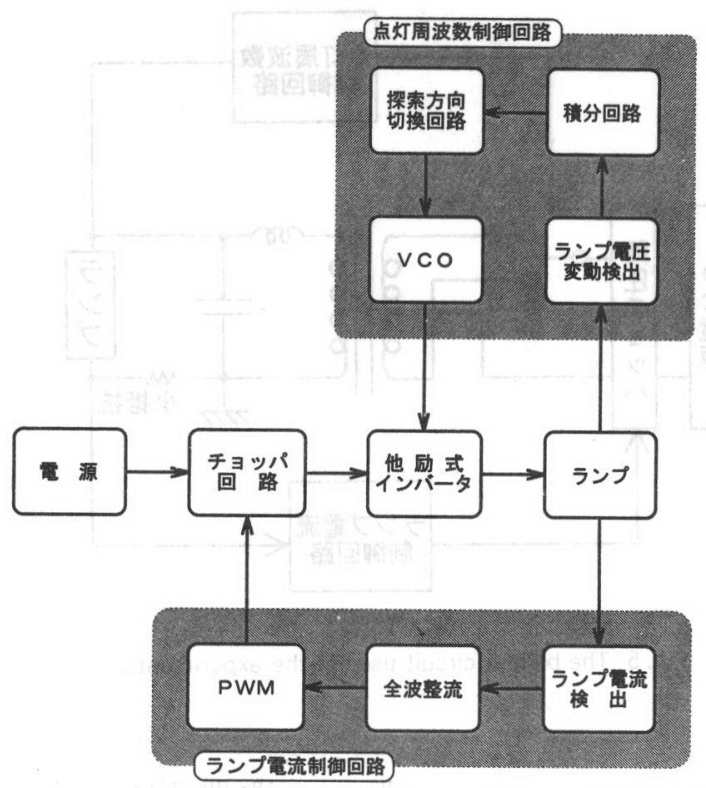

図 3 点灯回路の基本構成

Fig. 3 Basic configuration of the ballast.

チラツキを感ずることがある。このため(a)のように往復して探す ことにした。

点灯回路は図 3 に示すように, 他励式インバー夕, 周波数制御 回路，ランプ電流制御回路およびチョッパ回路より成る。

始めに, 周波数制御回路について説明する. 変動検出回路では, ランプ電圧を包絡線検波 (高周波の検波) する.この出力の中の 交流成分がランプ電圧の変動分であるので，これを検波（低周波 の検波）する.この検波出力がランプ電圧の変動の大きさを示す 信号である。この信号をコンパレー夕を経て積分回路に送る。探 索方向切換回路では, 周波数が下限または上限に達したことを検 知して, 周波数をシフトする向き (增加か減少) を切り換える. ランプ電圧の変動が設定值以上になると VCO (電圧制御発振器) の制御電圧が変化し周波数をシフトする。ランプ電圧の変動が小 さくなれば VCOの制御電圧の変化が止まり周波数は保持され る.このようにして安定点灯周波数を見つける.

次にランプ電流制御回路について述べる. ランプ電流(高周波) を op. amp を用いた全波整流回路により直流電圧に変換する.こ の電圧と設定值との差が PWM (パルス幅変調回路)に加えられ, ランプ電流を設定值に保つようにチョッパ回路のデューティ（時 比率）を制御する。この回路により, 電源電圧やランプの等価抵 抗が変化しても, ランプ電流を一定に維持する。

\section{3. 実験結果}

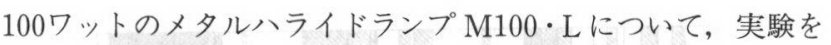
行った. 発光管の形状を図 4 に示す。このランプを図 5 に示す回 路により点灯した。インパー夕には, トランスの1次側電流の向

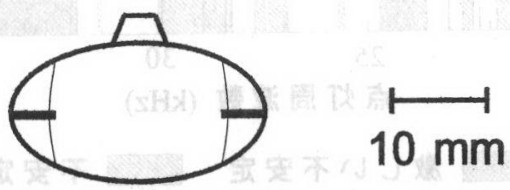

図 4 実験に使用したランプの発光管

Fig. 4 The arc tube of the lamp used in the experiments. 


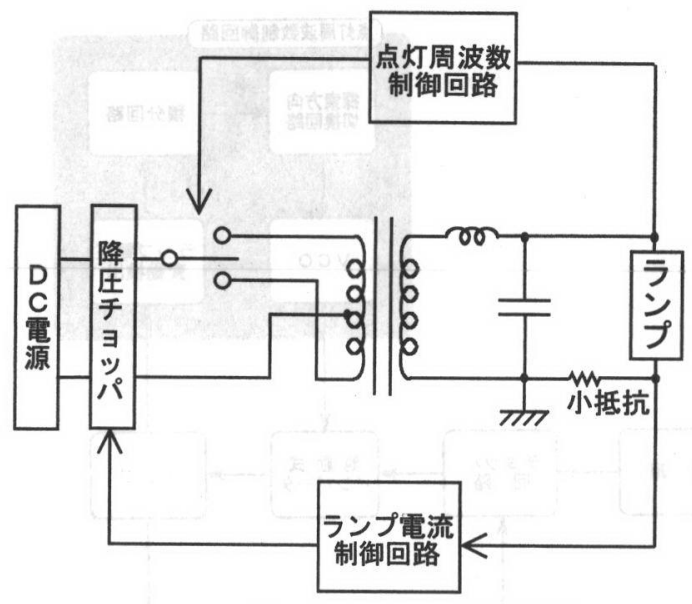

図 5 実験に使用した点灯回路

Fig. 5 The ballast circuit used in the experiments.

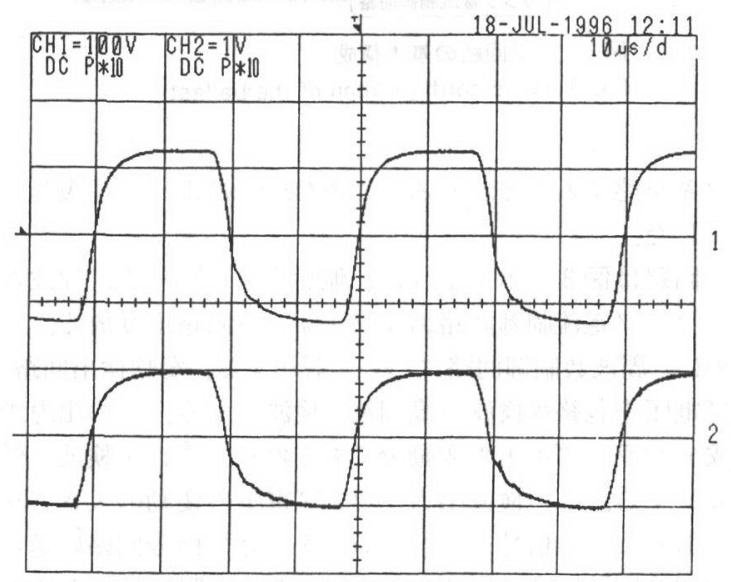

図 6 安定点灯時のランプの電圧電流波形

（上側：ランプ電圧 $100 \mathrm{~V} / \mathrm{div}$, 下側：ランプ電流 $1 \mathrm{~A} / \mathrm{div}$, 横軸：時間 $10 \mu \mathrm{s} / \mathrm{div})$

Fig. 6 Wave-forms of lamp voltage and current in stable operation (upper side : lamp voltage $100 \mathrm{~V} / \mathrm{div}$, down side:lamp current $1 \mathrm{~A} / \mathrm{div}$, time 10 $\mu \mathrm{s} / \mathrm{div}$ ).
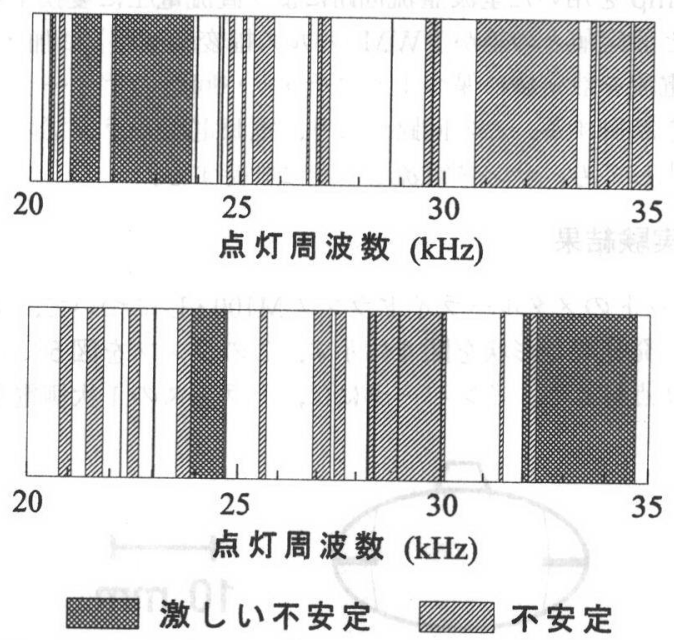

図 7 メタルハライドランプ M $100 \cdot \mathrm{L}$ の周波数特性

Fig. 7 Frequency characteristics of metal-halide lamp M100•L.
きを2個のスイッチ（パワートランジス夕）で交互に切り換える 方式を用いた。このままでは出力が矩形波となるので, 高次の高 調波をカットするためトランスの 2 次側に LC フィル夕を入れ た. 図 6 に安定点灯している時のランプ電圧波形（上側）と電流 波形（下側）を示す。

このインバータにより点灯した時のランプの周波数特性を，図 7 に 2 個のサンプルについて示す. 尚, この特性は周波数制御回 路の周波数シフト機能を停止して, 手動で周波数を変えて測定し

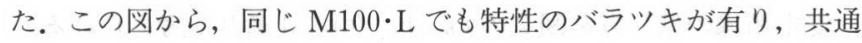
の安定周波数領域が狭く，固定周波数による安定点灯が困難であ ることがわかる。

次に, 点灯周波数の下限 $\mathrm{f}_{\min }=20 \mathrm{kHz}$, 上限 $\mathrm{f}_{\max }=25 \mathrm{kHz}$ とし て点灯した結果について述べる。始動後にランプ電流を 6 分間嵒 で0.8A $\rightarrow 1 \mathrm{~A} \rightarrow 0.6 \mathrm{~A} \rightarrow 1 \mathrm{~A} \rightarrow 0.8 \mathrm{~A} \cdots$-... と変えたときの点灯周 波数とランプ電圧の変化を測定した。 4 個のサンプルについての 測定結果を図 8 (a) (d)に示す。尚，このグラフは15秒間隔の測定 值により作図されたものである.

実際の使用では，このようにランプ電流を大幅に変化させるこ とは無いと思われるが，安定周波数を自動追尾する機能を確認す るため, ランプ電流設定值を手動により大幅に変化させてみた。 点灯中にランプ電流を急変させても, 新しい安定周波数に自動的 にシフトして安定点灯を続けた。光のちらつきは, 周波数が急変 するときに感じられる程度であり，この光の下での作業には支障 がないと思われる。

また, ランプ電流一定の場合でも勿論問題無く安定点灯を続け る. ランプ電流を $0.8 \mathrm{~A}$ に設定し長時間点灯した時の一例を図 9 に示す。この図で，2 時間経過以後に周波数が緩やかに下降して いるが, これは積分回路のコンデンサの電荷が, 漏れ抵抗により
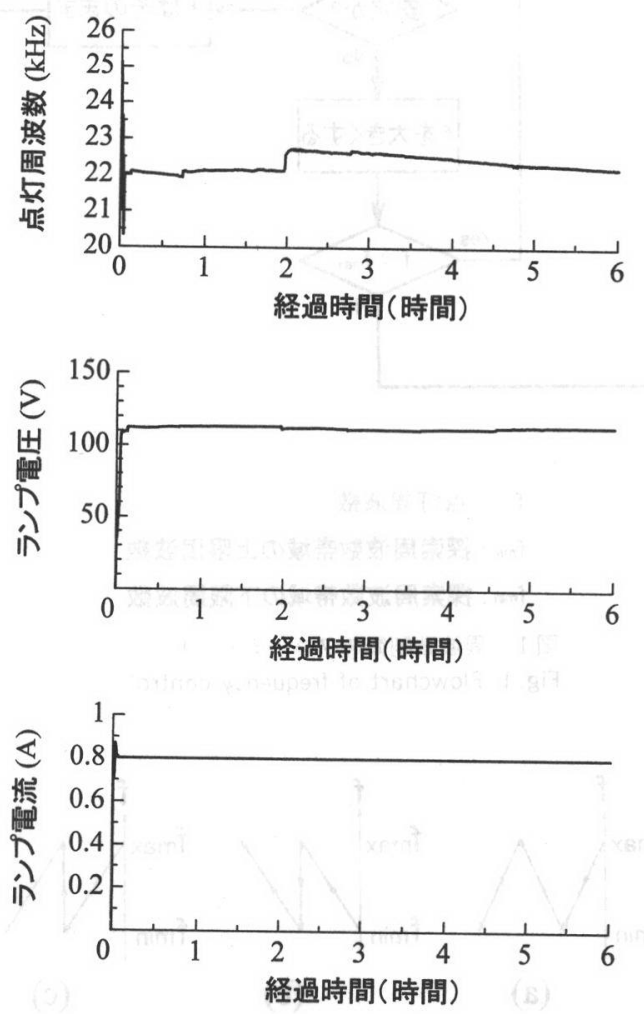

図 9 長時間点灯における点灯周波数の変化

Fig. 9 Change of operating frequency with operating time. 

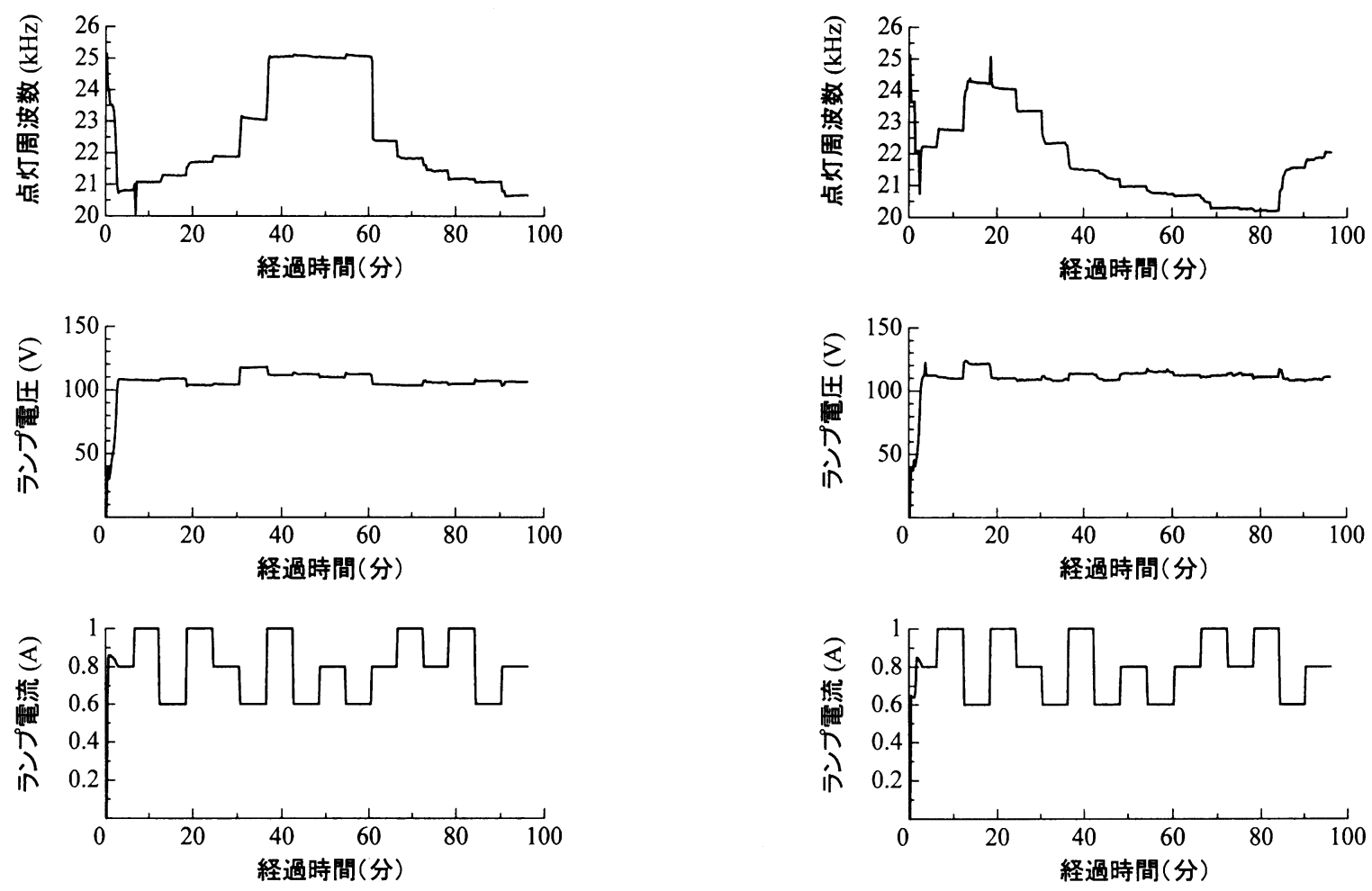

(a)

(b)
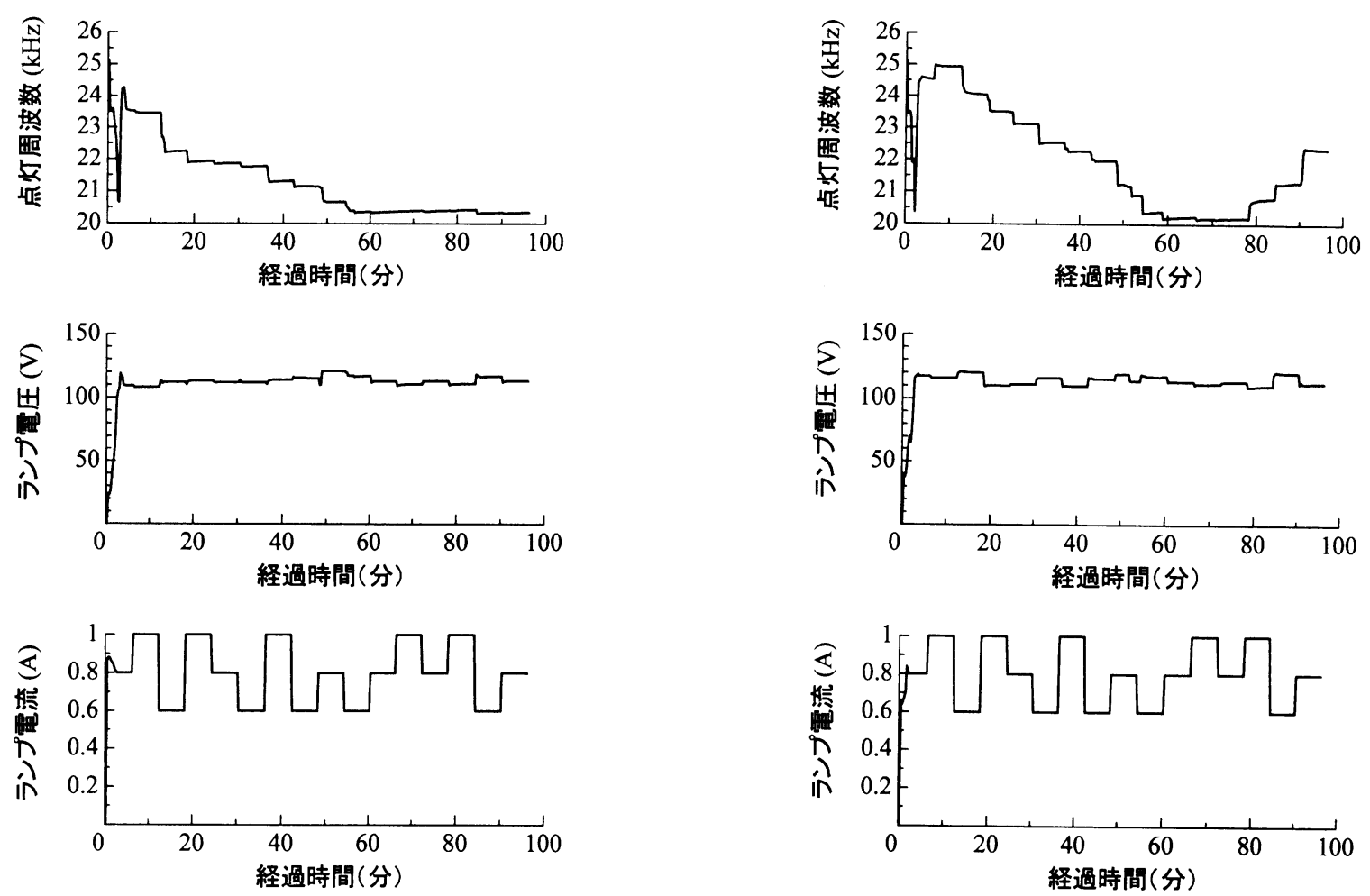

(c)

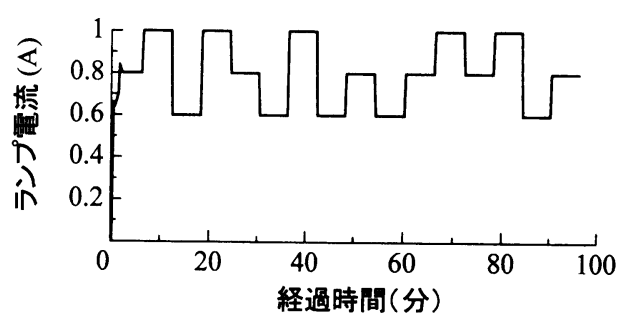

(d)

図 8 ランプ電流の変化による点灯周波数の変化

Fig. 8 Change of operating Frequency with change of lamp current. 

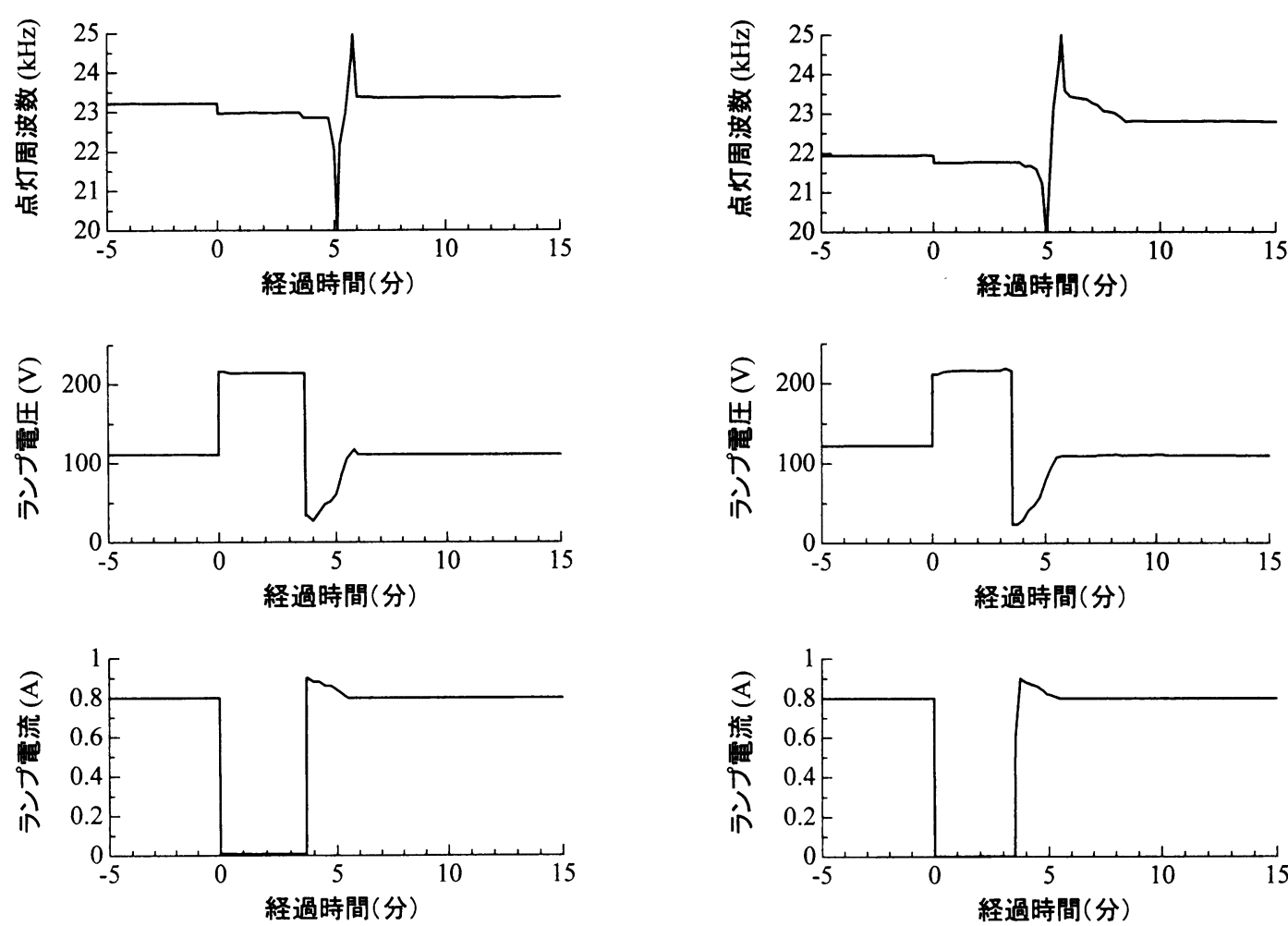

(a)

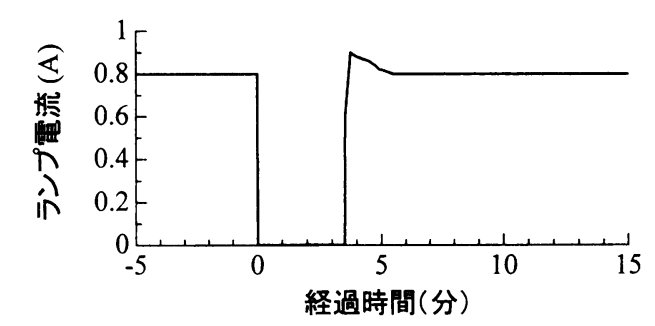

(b)
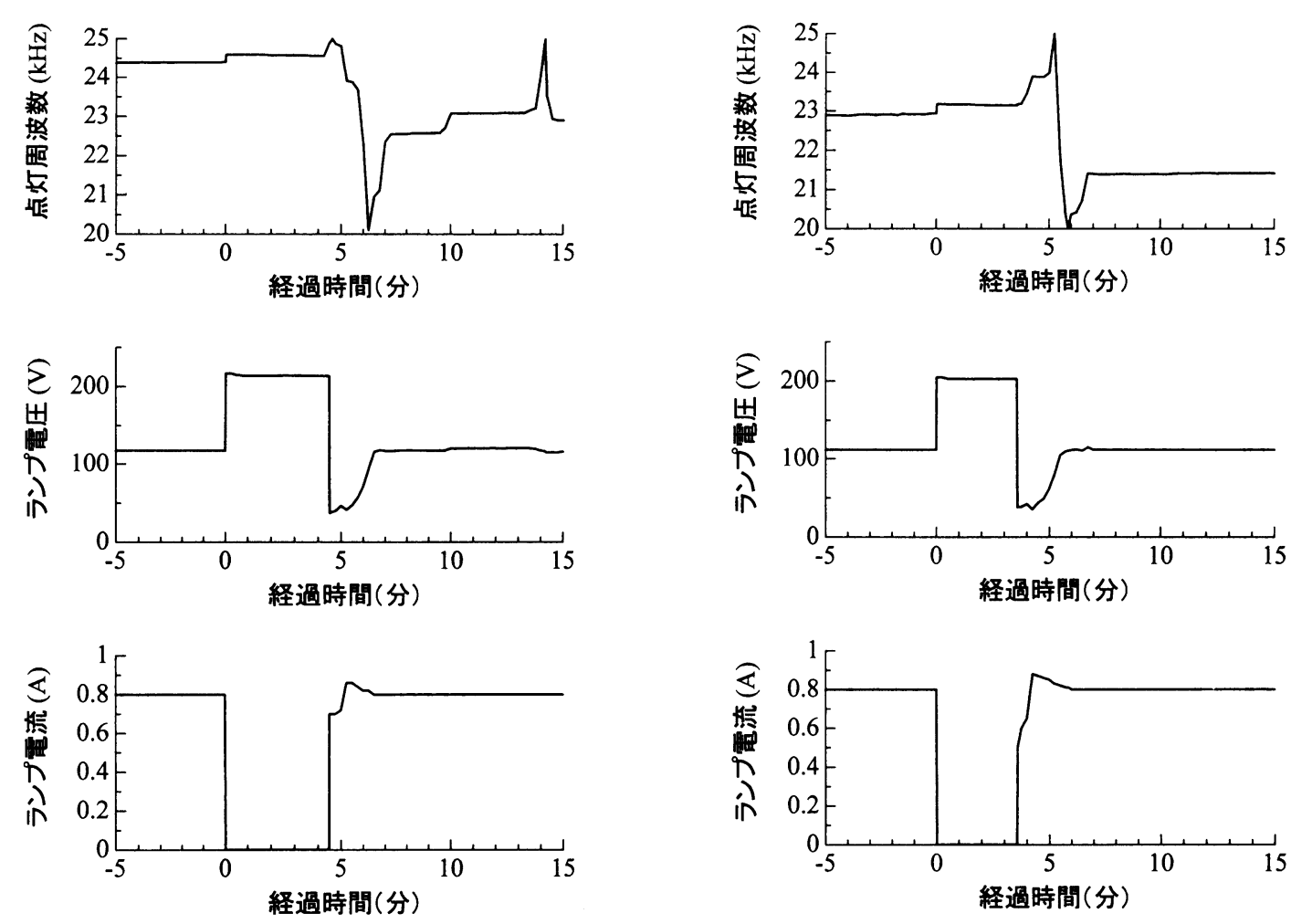

(c)

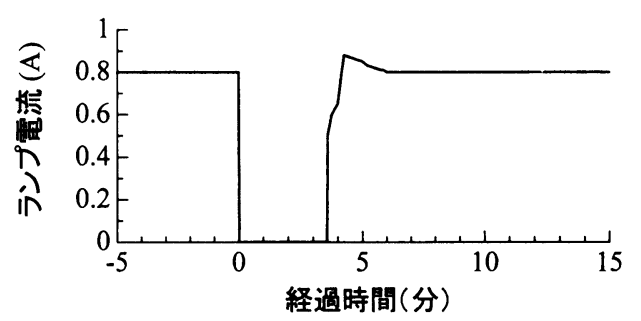

(d)

図10 再点灯特性

Fig.10 Restarting characteristics. 
放電し, VCO (電圧制御発振器) の入力電圧が低下するためであ る. 例之ば容量 $\mathrm{C}=500 \mu \mathrm{F}$, 漏れ抵抗 $\mathrm{R}=100 \mathrm{M} \Omega$ のコンデンサで は時定数 $\tau=5 \times 10^{4} \mathrm{sec}=14$ 時間となり，1 時間後には $\exp (-1 /$ 14）=0.93より電圧は $7 \%$ 低下する.この程度の漏れ抵抗であれば 実用上支障はない，漏れ抵抗のため周波数が変化して不安定領域 に入っても, 周波数制御回路により安定周波数領域に戻されるか らである。

次に, 再点灯特性について述べる. ランプ電流 $0.8 \mathrm{~A} に て$ 連続点 灯中に, 電源電圧を一瞬下げて消灯させたときの再点灯特性を測 定した. 4 個のランプについての測定結果を図10に示す。尚, 消 灯した時刻を時間軸のゼロとしてある．消灯直後のランプ電圧は

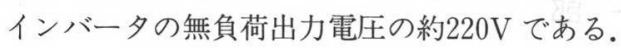

消灯後約 4 分で再点灯する.再点灯直後はランプ電圧が低いが, 約 2 分で概ね定常值に戻る. 図10の(a) と(b)は, 周波数制御が下向 き探索の時に消灯させた場合の例である．消灯した瞬間にはラン プ電圧が上昇し, この電圧変化により周波数は少し下向きに変化 する．消灯中はランプ電圧（インバータの無負荷出力電圧）の変 化が無いので, 周波数は一定に保たれる. 再点灯後はランプ電圧 の変動が大きいので, 周波数変化は急速である，最初，周波数は 下降し，下限に達すると上昇に転じ，上限に達すると再び下降す る. 約 2 分後にはランプは定常状態に近くなり, 激しい周波数変 化は止まる．また，図10の(c)と(d)は周波数制御が上向き探索の時 に消灯させた場合の例であり, 同様に再点灯後の約 2 分間は周波 数は激しく変化するが, その後は定常状態に近くなる。このよう に, 再点灯の場合にも, 周波数制御回路は正常に動作することが 確認された.

\section{4.あとがき}

メタルハライドランプを, 音響的共鳴現象のため困難とされて いる10 $100 \mathrm{kHz}$ 帯の周波数にて安定に点灯するため, 安定点灯 周波数を自動的に探す方式について実験を行った.

メタルハライドランプでは安定点灯する周波数帯は狭く, 同じ 規格のランプでも周波数にバラツキがあるが, この方式では設定 した周波数の上限と下限との間を往復掃引するので，この間に 1 個以上の安定周波数領域が存在すれば良く, 安定周波数の值にバ ラツキが有っても差し支えない。また，点灯周波数の上限と下限 の值やランプ電流などを回路基板上の半固定抵抗器で設定できる ようにすれば, 1 種類の基板を多種類のランプに利用できるとい うメリットが生まれる.

この方法では, 矩形波点灯や周波数変調点灯に比べて高次の高 調波が少なく，放送，通信への妨害が小さいという長所がある.
また，10〜 $100 \mathrm{kHz}$ 帯はスイッングレギュレータ関連の技術や 製品（IC，トランジスタ，トランスなど）を利用できるという利 点もある.

以上, HID ランプ安定器の研究の一助になればと思い発表する 次第です.

\section{参 考 文 献}

（1）越村, 青池, 小林, 野村：「HID ランプの高周波点灯にお ける放電安定化方法」, 照学誌67-2 p.55-61 (1983)

(2) 吉川, 青池：「HID ランプの高周波点灯における放電ア一 ク不安定性の新しい抑制法」, 照学誌77-10p.619-626(1993)

(3) 岡田, 森井, 和田 : 「音響的共鳴現象を防止した HID ラン プの研究」, 照学誌71- 6 p.339-343 (1987)

(4) 永瀬, 西村, 内橋, 塩見：「高圧放電灯用電子点灯回路の 研究」, 照学誌72-2 p.85-90 (1988)

（5）中西, 井上, 小松原, 姫井 : $\lceil 100 \mathrm{kHz}$ 以上の高周波による HID ランプの点灯」, 照学誌70-2 p.62-66 (1986)

(6) 水野, 石川：「メタルハライドランプの高周波点灯のマイ クロコンピュータ制御」, 照学誌71-10 p.622-625 (1987)

(受付日1996年 8 月 5 日/採録日1996年11月 5 日)

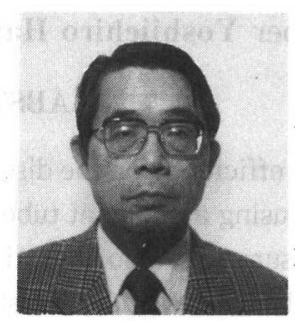

\section{水野 銛章 (専門会員)}

名古屋工業大学電気情報工学科

昭和 8 年 6 月生. 昭和 36 年 3 月名古屋大学 大学院工学研究科電気工学専攻修士課程修 了. 昭和 39 年 4 月名古屋工業大学電子工学科 助手. 講師を経て, 現在電気情報工学科助教授. この間, 半導体 工学, 電子管, 電子回路の講義を担当し, 半導体素子及び電子回 路に関する研究に従事. 電気学会, 電子情報通信学会会員.

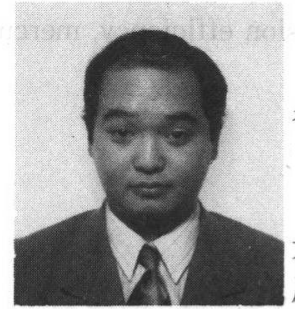

林宏宜 (非会員)

名古屋工業大学電気情報工学科

昭和 46 年 12 月生. 平成 7 年 3 月名古屋工業 大学工学部電気情報工学科卒業. 現在, 名古 屋工業大学大学院工学研究科電気情報工学専 攻在学中. 電子回路, 放電ランプ点灯回路に関する研究に従事. 電気学会会員. 